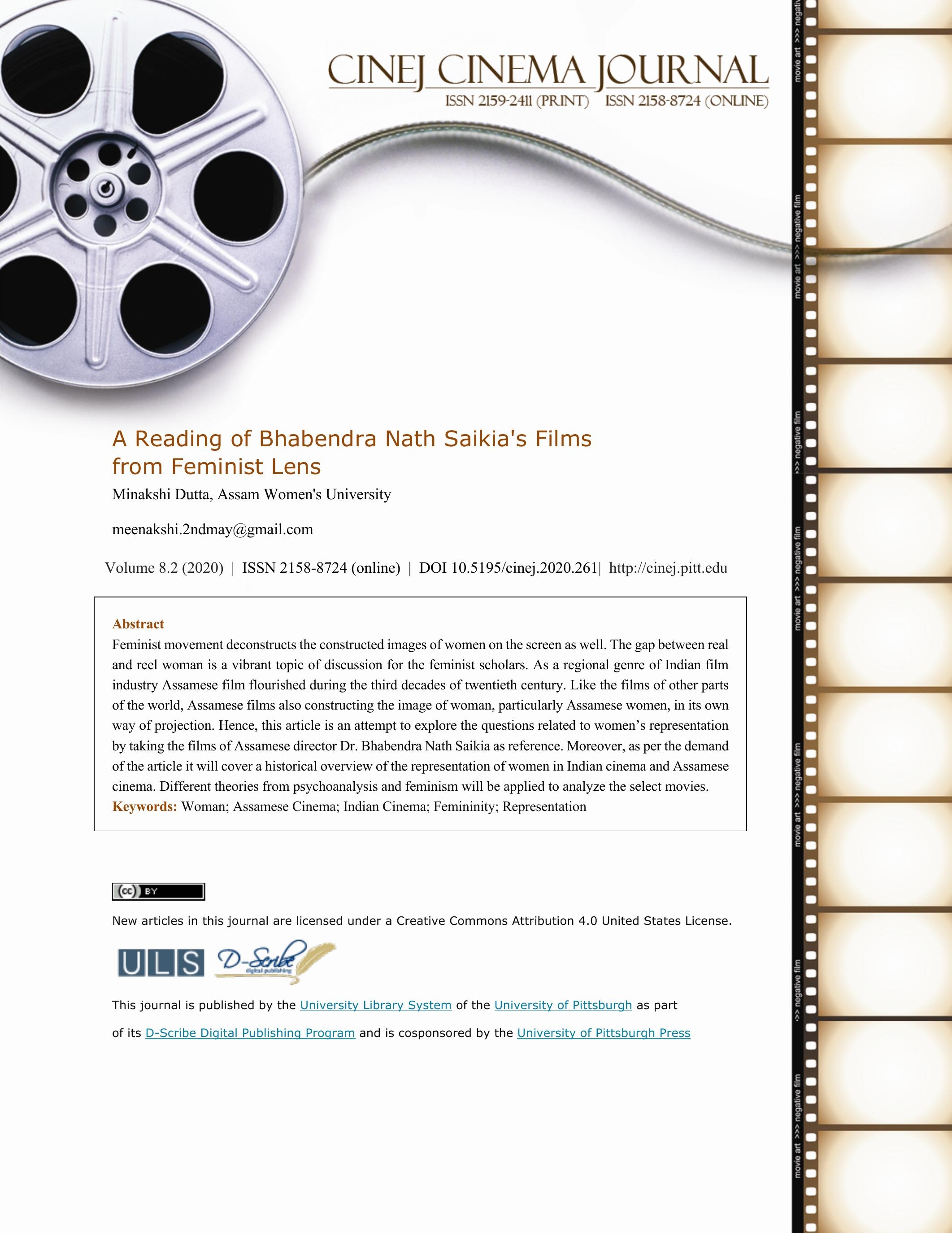




\section{A Reading of Bhabendra Nath Saikia's Films from Feminist Lens Minakshi Dutta}

\section{Introduction}

Women are constantly projected on the screen since its inception. However, the question on its representation was raised after the emergence of feminist movement. Feminist film critics apply psychoanalytic theory, semiology and historical materialism to investigate the ongoing stereotypical projection of woman. How the interpretations are made through various modes of communications like language, literature and film is the prime concern for feminist critics. In the representation of women 'what really matters is not so much the type of woman the fictive character in the film represent, but what she comes to signify within the whole textual system of the film's narrative (Hayward 2000: 208).Under-representation and misrepresentation of women in cinema causes the growing interest of feminist scholars in cinema. In their academic writings they concentrated on the study of how meaning in produced in communications systems such as language, literature, and films to suggest a more sophisticated and nuanced approach in this movement. Apart from that they dealt with some pertinent questions like, how does the feminist agendas are visible in cinema, what is the filmmaker's understanding on feminism, how women are represented on the screen, what is the role of the female film-makers in depicting the women's issues, how women's issues are projected in cinema etc. The whole idea of woman is human construction. In The Second Sex, Simone de Beauvoir wrote that 'one is not born, but rather becomes, a woman (Beauvoir 1993: 281)'. And according to her 'religion, traditions, language, tales, songs, movies' help the society to understand and experience the world. She is defined by a patriarchal lens. Marjorie Rosen's book Popcorn Venus: Women, Movies and American Dream (1973) and Molly Haskell's From Reverence to Rape: The Treatment of Women in the Movies 
(1974) were considered to be the first step towards the investigation of woman representation on celluloid. They argued that 'women on the screen are often nothing more than cultural stereotypes of women- the flapper, the vamp, the virgin, the Madonna, the femme fatale, the gold digger, the hooker with a heart of gold (Fabe: 2004:208)'. According to them 'woman's image of herself is so entwined in the tangle of myths and inventions made by man that it is hard to look at its straight (Haskell: 1987: 278). With this they help to understand how representation is intricately linked to 'patriarchal myths, values and opinions (McCabe: 2004:10)'. After that representation of woman in cinema was explored from various approaches. Semiotic and psychoanalytic theories are popularly used by the feminist scholars to uncover the ways of woman representation in cinema. Laura Mulvey's famous article Visual Pleasure and Narrative Cinema brings a vibrant approach in the study of woman representation in cinema. The idea of 'male gaze' is elaborately explained by her to deconstruct the reality of female subjectivity on the screen. According to her, 'women in films play a secondary and more ornamental role for the male audiences in the traditional cinema (Mulvey: 1975)'. Even her story captured in narrative cinema is also from male perspective. She is not free to express her own words.

Budd Boeticher's statement about the narrative cinema of the west establishes that women in this are relegated to the background. According to Boeticher,

What counts is what the heroine provokes, or rather what she represents. She is the one, or rather the love or fears she inspires in the hero, or else the concern she feels for her, who makes him act the way he does. In herself the women has not the slightest importance (Jain\& Rai: 2002:52).

In cinema women are 'coded for strong visual and erotic impact so that they can be said to connote to-be-looked-at-ness' (Mulvey: 2009:19) to perform her 'traditional exhibitionist role'. Even the stories of the films are the men's- their dreams, aspirations, heroism. Women are just for 
men's sake. They are displayed as an object for the characters within the story and as an 'erotic object' for the spectator. E. Ann Kaplan observed that,

this is not to deny that women have a history of their own which can, to some extent, be rediscovered; but it is to argue that in terms of dominant film narratives, of classic forms, women, as they have been represented by men in these texts, take on images that have an 'eternal' status, and are repeated through the decades in their essentials: the representation changes superficially in accord with current styles and fashions-but scratch the surface and one finds a familiar pattern. (Kaplan :1983)

\section{Popular Images of Assamese Women:}

In the nineteenth century a model of 'Indian womanhood' was created in the popular imagination in the response to colonial rule, and jettisoning it has been difficult. Art, literature, drama and poetry amalgamated to mold a popular vision of Indian womanhood, but the version of the 'new' woman was actually the modernists' reinvention of the traditional Indian woman tempered by the mix of dominant Victorian and upper-class Brahminical values (Virdi :1962:61-62).

Assamese woman also go through such process. Assamese drama, art, literature shaped an image of Assamese woman with its creation. Indeed, this representation was fully stereotypical in nature. Sometimes, these literary creations criticized the changing nature of new woman. Famous Assamese litterateur LaxminathBezbarua described Assamese women in the following statement, you have abandoned your riha-mekhala (Assamese traditional dress for woman)and are wearing saris now, well please do so as your dangorias are pleased to see you in such dresses...you have set aside your traditional handloom and have learnt to knit woolen socks, ganji, frock; go ahead (Medhi: 2014:89). 
These types of writings create an image of Assamese women in the minds of people. During his visit to Assam in 1921, Mahatma Gandhi wrote the following lines in Young India (1921) by praising Assamese women- 'And, of course, I feel in love with the women of Assam. They are like women all over India shy, modest with extremely refined and open faces (Saikia 1992:39)'. Although, the status of Assamese women is much better than the women of other parts of India. Impact of many ethnic groups residing in this region makes the socio-cultural situation of Assam a distinct one. Some practices like dowry, Sati Pratha were not so common in Assam in the ancient period. From medieval to modern period, women of Assam enjoy a special status in Indian history. In post-independent period, they have made remarkable progress in socio-economic and cultural fields. Though in earlier times women were only associated with household works, after the introduction of education they are able to enter into the working places also. It enhances their position both inside and outside the home. However, the women are still facing some socioeconomic and political problems in their day to day lives. But surprisingly, in popular imagination these types of problems hardly find any place in such creations. It follows a stereotypical form of representation to create an ideal woman in the nationalistic imagination. However, some writers like Laxminandan Bora, Bhabendra Nath Saikia, NirupamaBorgohain, MamoniRoysom Goswami brings a new image of Assamese women. Their women characters can fight for their rights and identity. Thus, a dual image of Assamese woman is constructed in literature and other artistic composition.

\section{Women in Assamese Cinema:}

The history of Assamese film starts with the woman centric filmJoymati of Jyoti Prasad Agarwala in the year 1935. Though Joymati was a historical figure, the narrative as well as the cinematic treatment had projected a strong woman in political sense. With her silence the director signifies the desirable character of an Assamese woman. In the whole movie Jyoti Prasad 
Agarwalahad given special focus on the character of Joymoti. He explains the character of Joymoti in the following lines,

I have tried to direct the film as well as its characters realistically. The same realistic portrayal of the characters is also noticeable in the first class English, American and Russian films. That is why Joymoti of my film neither speaks much at the royal court, not speaks publicly in any place. She is represented as a stoical 'alpa-bhasini' Assamese aristocratic bowari (daughter in law) who maintains silence, speaks only when required proves herself through her actions....I have sketched out the character of Joymoti following my understanding of the Assamese woman. Silence is one of the features of the Assamese character. It is the quality that I have tried to highlight in my portrayal of Joymoti” (Agarwala: 2003: 537-538).

This is how Assamese woman was defined by Agarwala at the middle of twentieth century. After that, Assamese women were represented differently in different films. But her role is confined to her societal role of a simple daughter, ideal daughter-in-law, sacrificing mother, obedient, subordinate wife, etc. The issues of women's representation are closely related with the 'real' and 'imagined' images of women. How much the representation is closer to reality is the main question in feminist reading. Assamese women are enjoying more freedom than the other parts of India. After Agarwala, lots of Assamese movies were produced. But they were mainly commercial in nature. Women were projected in their so-called stereotypical role. Films like Bowari (The Daughter in Law, 1982), Aparoopa (1982), Nayanmoni (1983), Ghar Sansar (1983), Papori(1984), Mon Mandir(1985), Puja (1985), etc were some of the famous film of that period where the women were shown as ideal daughter-in-law, ideal wife and simple village girl suffered from patriarchal values. 
Paralleling to the other film industries of India (Bengal, Maharashtra, Tamil, Telugu), in this North Eastern part also, the wave of neo-realism impacted the Assamese film industry. PadumBarua with his one and only movie Ganga ChilonirPankhi (Feathers of the Kite, 1976) opens up a new way of filmmaking for his successors. This movie was also about a pathetic story of a widow. How she is trapped in the manmade society and had to suffer in her life- is realistically depicted in the film. In this movie the protagonist Basanti, at the end of the movie, surrendered to the patriarchal norms. After Barua, some other prominent filmmakers also attempted to make films on women's issues. Among them Dr. Bhabendra Nath Saikia, JahnuBarua, SwantanaBordoloi, Manju Borah were mentionable. Immediately after Barua’s film, Sandhyarag (1977) and Agnisnan (1985) of Dr. Bhabandra Nath Saikia, with the projection of female subjectivity were released. Both the films were set in the colonial and post colonial society of Assam. Sandhyarag projects the struggle of a female protagonist in an urban middle class society, whereas Agnisnan represents the protest of a middle class woman of pre-independent era. However, Saikia's Agnisnanwas completely different from the earlier woman centric film in its treatment of the narrative. Here we find a rebellious and strong woman character within the protagonist (Menaka). She had a voice of her own. After him JahnuBarua, an alumni of Film and Television Institute of India (FTII), came up with two woman-centric films: Aparoopa (1982) and Papori (1986). Both the films were based on the inner and outer struggle a woman had to face in her life. In Aparoopa, the protagonist fights with her loneliness and depression and at the end decided to find her way with her ex-lover. And in Papori, the protagonist, a simple housewife "trapped in nightmarish circumstances with the student unrest in Assam" (Senapati 2007:94). Dr.Swantana Bordoloi had gifted a remarkable woman centric movie to the Assamese film industry. Her film Adajya (1996) based on the famous novel of Assamese literary icon MamoniRoisom Goswami, DantalHatirUiyeKhowaHaoda (The Moth Eaten Howda of the Tusker, 1988) is a story of the measurable life of three widows. 
The film takes a dig at social norms and orthodox value system which always reduce men's better halves to a suffering lot. The poignant way and subtlety the director adopted to establish her statement made the film a democratic feminist critique (Borpujari: 2007:106).

Another movie AkashitorarKathare (A Tale Told a Thousand Times, 2003) by Assamese female filmmaker Manju Borah is also an important movie for this discussion. It is a story about an educated woman who had to sacrifice her bright career for upbringing her family. National film critic Manoj Borpujaricommented on this film as such

This is a strong unconventional portrayal of a woman protagonist rarely seen in Assamese cinema. Obviously this film touches a thread of woman lib movement sans the pro-activist as it shows a passive protestor who ultimately refuses to toe the happy-golucky housewife's line of thinking (Borpujari:2007:106)'.

In this movie also the protagonist died at the end of the movie. Arup Manna, another upcoming director made a movie on the autobiography of AideoHandique, the heroin of Jyoti Prasad Agarwala'sJoymoticalled Aideu (2006). The film describes the challenging life history of the first Assamese film actress. The film is the

Visualization of the tale of the gifted actress who is ostracized by her own society for acting in cinema. That was a time when co-acting was a taboo, females were not allowed to have a glimpse of even Bhaona, the few hundred years old folk theatre of Assam (Ibid: $113)$. 
In this way woman is represented in Assamese film. The style and techniques of projection has changed but the perspective is same i.e. patriarchal.

\section{Women in Bhabendra Nath Saikia's Cinemas:}

Dr. Bhabendra Nath Saikia (1932-2003) has been one of the few prolific and serious film directors from Assam(India) who earned his distinction in film-making through his seven Assamese films, namely, Sandhyarag (Cry of Twilight, 1977, B\&W), Anirban (The Vigil,1981, B\&W), Agnisnan(The Ordeal,1985, Colour), Kolahal(The Turmoil, 1988, Colour), Sarathi (The Shelter, 1991, Colour), Abartan (On the Run,1993, Colour) and Itihaas (Exploration, 1996, Colour). Each one of this handful of collection earned positive responses from both the general audience and critics. Amongst the various features about Dr Saikia'sfilm-making, one thematic characteristic that is overtly visible in all his films is the attempt to depict, often critically, a world of the Assamese middle class population of the post-independent times of a newly urbanized and industrialized Assam.

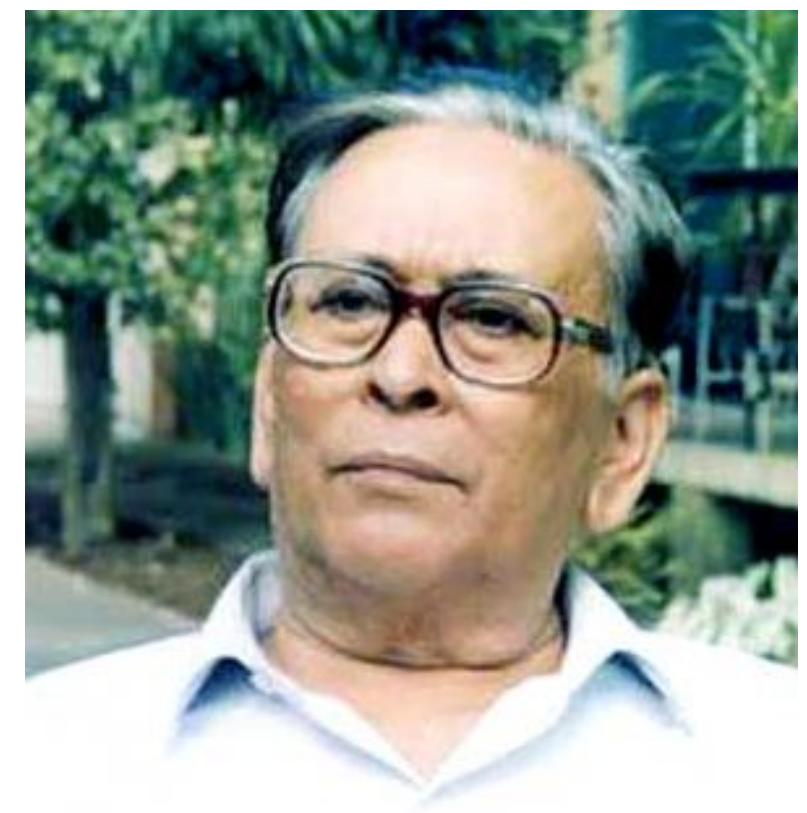

Figure 1: Filmmaker Dr. Bhabendra Nath Saikia (1932-2003) 
Saikia's oeuvres portrayed the plight of women functioning within a patriarchal society with great sensibility. He had a distinctive ideological standpoint and felt strongly that films must be a medium to represent the reality. His seven films embarked on a series of woman-centered films, which are tied up with historical insights. Saikia's perceptions reflect in the establishment of the women's sensitive issues on the screen. Through his films he constantly raised the questions about gender exploitation in a patriarchal society. Some of his works radically challenged the conventional notions of womanhood. In his movies from Sandhyarag to Itihaas, he explored the life and struggle of the women from different sections of the society- working class, middle class and a woman from an urban area. Amalgamation of submissive and rebellious, ideal and disturbing woman character in a single story is a distinguishing feature of Saikia's films. In his films a range of issues related to woman are covered. In this chapter, some of those issues will be analyzed from both cultural studies and feminist perspectives.

In Sandhyarag we find women from two opposite stratum -rural/ rich and urban/ poor. Their social status creates a difference in their character composition on the screen. Saru, Taru and Putuli represent the rural working-class women, whether Kanta, Mrs. Das and her friend Urmila are the agents of urban middle-class women. The above-mentioned categories enjoy power or status according to their socio-economic condition. In this film one marginalized group exploits another marginalized group of the society. First encounter between these two groups is showed with some POV shots at the moment of Saru's entry to her owner's house with her new identity as a housemaid. Both Saru and Kanta looking to each other with a surprising look as if one is stranger for the other. A clear distinction is evident in their attire, body gesture and talking style. All these represent their power and position within the film narrative. One is confident and charming, while other is hesitant and monotonous. 
According to Fredrick Engels, 'the middle-class woman is totally dependent on her husband and is therefore her property. The women of working class by participating in the production in a way challenge their exploitation (Brewer: 2004)'. After the death of her husband Putuli tried to survive by selling vegetables in the village market, whereas Mrs. Das had to wait for her husband's consent in each and every household matters. Interestingly, within this middleclass category Saikia had depicted two different types of women. One is considerably good than the other. Saru's owner Mrs. Das is kind-hearted than Taru's owner Urmila. Apart from their activities, their physical appearance also reflects their character.

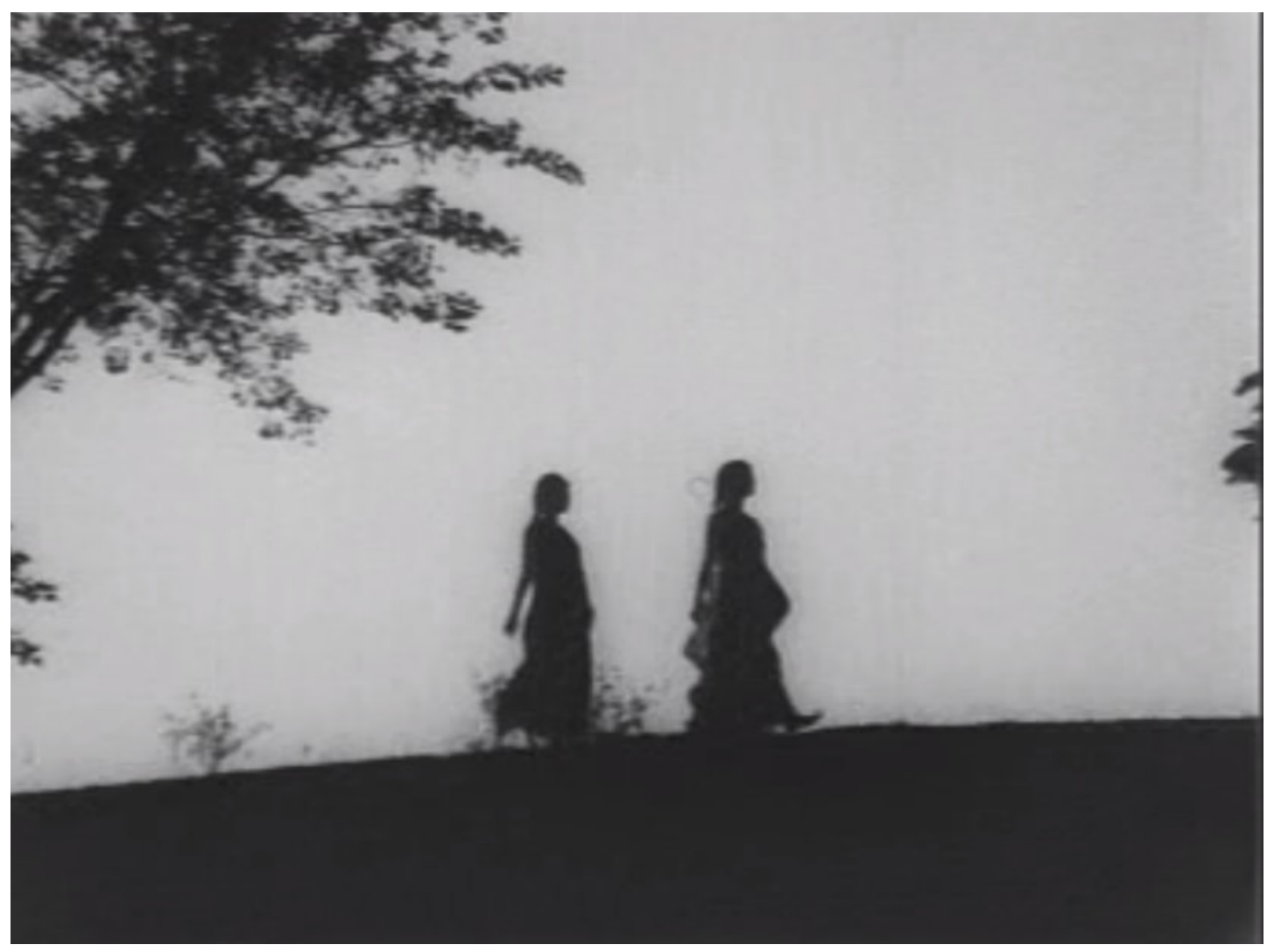

Figure 2: A snapshot from Bhabendra Nath Saikia's film Sandhyarag

Clothing becomes an important factor in the communication of socio-cultural meaning in a given society especially a country like India where dress is 'directly related to and dependent 
upon her relationships to others and her social role(Macdonald: 2009:4)'. In films clothing articulates some semiotic meaning beyond its anthropological necessity. Film directors commonly used clothing as a tool to place a character in front of the audience as per the demand of the personality of the character. In Bollywood movies woman with traditional dress showed as a so called 'ideal' woman, whereas western clothing suggests her negative character. Likewise, sometimes over make-up also exemplify the negativity of a character. This conventional strategy is applied by Saikia in his movies to articulate specific meaning through a character. Mrs. Das' dressing style is noticeably different from that of Urmila. High make up of Urmila shows her insensitive and cruel character in a lucid manner. Same can be observe in the film Sarothi, where Niranjan Dutta's 'ideal' life partner is constructed with her traditional and disciplined attire and she is distinct from her real wife, who wears fashionable dress with high make-up, in this respect.

Class plays an important role in the construction of gender identity. In Malini Bhattacharya's words,

Class is a category which enables us to historicize 'gender' to trace the development in time of the concept. The evolution of the man-woman relationship in society or of gender politics, while it has its own internal logic and seems at times to operate independently of class differentiations can nevertheless only be understood in the context of the organization of production relations within a particular social structure. Such a perspective enables us to specify gender relations. It also opens out continually to include the complex interplay of gender relationships with other social relationships (Mazumdar: 1991:81).

In some of his films Saikia had try to locate gender distinction through an array of social categories like class and caste. InAgnisnan we observe that, both Kiran and Madan are from lower 
stratum of the society who are voiceless and exploited by the members of upper class. Saikia had clearly portrayed the man-woman relationship within the class boundary. Sometimes, the class difference becomes more prominent as well as dominant than the gender difference. The relationship between Madan and Menaka and Kiron and Menaka shows that it is the class which demarcates their power and position in the society. Though Madan is a male member, in front of Menaka his position is weak and dependent. He is only a follower of her order. In the same manner as a female member of the society, who is supposed to be a subordinate and weak one, Menaka, in the film, enjoys enormous power. Kiron on the other hand exploited by both the male as well as female (Menaka) member of the society. In the film Menaka's character cross the constructed boundary of a female character and transformed into a 'malevolent aggressive destroyer'. Instead of staying silent like Kiron, she raised her voice against the system, against her betrayer husband. This act of taking revenge was highly criticized by the film critics but it was a bold step taken by an Assamese film director. During 1980s, a new 'formula' inaugurated by N. Chandra's film Pratighat (The Revenge, 1987) followed by Sherni (The Tigress, 1988),KhoonBhariMang (1988), KhoonBahaa Ganga Mein (1988),Commando (1988), Bhraschtachar (Corruption, 1989) and Kali Ganga. (Dirty Ganga, 1990).

'The common theme in these films ...is their portrayal of women as hardened, cynical, vengeful creatures' ... and that screenplays and powerful women are a welcome break from stereotypical roles as submissive and dutiful mothers and wives (Vasudevan 2000:216)'.

Saikia's Agnisnan is also replica of this category. Jyoti Prasad Agarwala in his Joymoti projected silence as a weapon against the Ahom Kingdom, whereas Saikia had defined Assamese woman in a different way. Her revengeful activities make a history in the representation of Assamese women on the screen. 


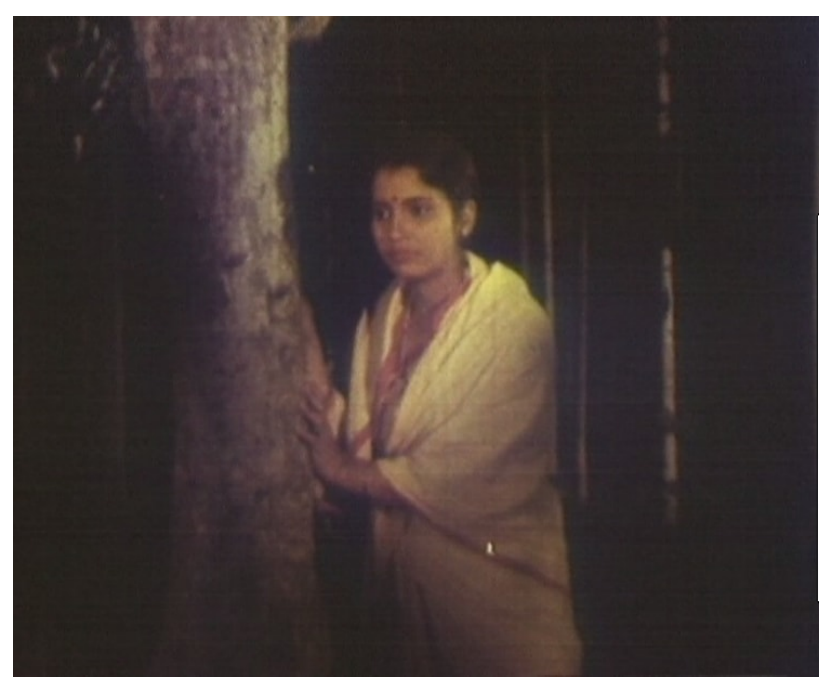

Figure 3: A snapshot from Agnisnan (1985)

Throughout the period of modernity, Enlightenment and Philosophical rationalism, human body has been theorized in diverse ways. Michel Foucault defined body in terms of power and discourse. In Discipline and Punish, he argued that "the 'soul' becomes a normative and normalizing ideal according to which the body is trained, shaped, cultivated, and invested; it is an historically specific imaginary ideal under which the body is effectively materialized (Butler 2013:9)". Feminist scholars focused attention on the "negative effects of social inscription on the body: the ways in which a society constructs meaning around the biological conditions of gender in order to discipline and control the body (Lewis: 2002:295)'. In Indian context, Meenakshi Thapan has noted that 'the female body becomes an instrument and a symbol for the community's expression of caste, class and communal honour. Chastity, virtue and above all, purity are extolled as great feminine virtue embodying the honour of the family, community and the nation (Thapan 1997:6; Macdonald 2009:4)'. Thus, women's body transformed to a bearer of honour of her family, community and nation. Her 'body is not so much a body of individuality but a 'body-for-others' 
(Ibid). Apart from that 'women often experience their bodies as shameful (Viswanath: 1997), having learned that there is nothing to be proud of in a woman's body (Das 1988:200 \& Macdonald 2009:4)'. This idea was challenged by the ècriture fèminism and looked into women's body from a different angle. This movement, emerged in France by several women writes including Julia Kristeva, Luce Irigaray, Judith Butler, and Cixous, was "a refusal to accept the traditional Western binary opposition of mind and body" (Huang 2004:15). Kristeva explored the cases of mother's body. While, Irigaray and Cixous go further and said that,

If women are to discover and express who they are, to bring to the surface what masculine history has repressed in them, they must begin with their sexuality. And their sexuality begins with their bodies, with their genital and libidinal difference from men (Jones: 2003: 366).

They viewed woman's body as her weapon against patriarchal society. This re-reading can be seen in the films of women filmmakers of Indian Diasporas, Mira Nair and Deepa Mehta. They established a new meaning of a woman body against the popular construction of an Indian female body. In the context of Assamese film industry also, Bhabendra Nath Saikia in his masterpiece, Agnisnan explores the body of a woman as a weapon for her revolt against patriarchy. Her bodily involvement with the lower-class man Madan shatters the esteem of Mohikanta or the male constructed role for women. Menaka declares a movement against the patriarchal society by becoming pregnant. Her socially constructed body helps her to raise her female voice. However, at the end of the movie, she cannot come out from the concept of purity-impurity and said 'I don't want to stay in the mud; I also become clean for the society”. Thus, she once again trapped into the patriarchal boundary. This kind of representation is common both in Hollywood and Bollywood. In their typical strong-woman films, they often portray a strong and ambitious career 
woman but at the same time she is weakened by subtle narrative effects. In the Hollywood film His Girl Friday (1940) the female protagonist Hildy, "for all her talent as a newspaper reporter, remains distinctly inferior to Walter Burns." The representation of a strong and independent woman is also not beyond the influence of patriarchal ideology. Shekhar Kapur's famous films Masoom (The Innocent, 1983) and Bandit Queen (1994) had projected two different kinds of women- an ideal mother or wife who has the capacity to accept the child of her co-wife and a woman who becomes a Bandit to take revenge. Aandhi (Storm, 1975) of Gulzar is a story about a woman who openly expresses her will and refuses to compromise with her fame and career for her husband. The difference between male and female in respect of their extra marital attraction is the main issue of Govind Nihalani's film Drishti (1991).Mahesh Bhatt's film Arth (Meaning, 1982)is a well representation of a woman who is betrayed by her husband for another woman and when the woman betray him once again he approaches his wife. When the wife asks him if he can accept her with such offence, he says no. This is the fact in reality also. Representation of gender and gender relations in popular culture normalize unequal power relations between men and women and links female identity to her sexuality. It works just like the ISA (Ideological State Apparatus) propagated by Louis Althusser, in making her position normal as well as natural.

Along with these issues Saikia highlighted some other aspects of a woman's life. In the early 1900's, women began entering the workplace but only if they were not married, had no children or were past the 'marriageable age'. It brings economic as well as social freedom for women. Indeed, they had to compromise with many aspects related to her physical and mental status. In Indian scenario, working women had to manage both the public i.e professional and private sphere. Social theorist Jurgen Habermas described public sphere as '[ ] ...a domain of our social life in which such a thing as public opinion can be formed (Robinson: 2011:8)'. 
Nevertheless, within gender discourse public and private sphere denotes the outside versus inside the home. Undoubtedly, women, as Hebarmas said, can acquire a space for 'public opinion' by entering into the public sphere. Along with freedom sometimes it brings a conflicting situation in their lives. It becomes difficult for them to keep balance between these two spheres of life. Abartan is a good example of such conflict. It in effect privileged the woman's story and her public and private life. Being a working woman, Jayanti had to face both familial and professional problems in her life. Her marriage is an undesired step for both her family members and the theatre group. The split between the public and the private is successfully depicted through the application of well-planned sets, shots compositions and camera angles. Her contract with the theatre owner is going to restrict her private life. In this regard we can mention about Benegal's Bhumika (The Role, 1977), where Usha (Smita Patel) is a film actress and exploited by different male members in her life. She is also fighting between public and private life. Money is associated with a working woman. It strengthens her economic position in the family; but at the same time, it keeps her away from the familial affection. In Jayanti's story also her earnings keep her away from family love. Her profession makes her an earning machine for her family members. Even when she thought about marriage, her family members stood against her due to their selfish motives. Apart from that, in certain cases, working women are not secured in their working place also. They had to face problems from her male partners. In a patriarchal society status of a housewife and a working woman is same. Her economic freedom cannot overcome certain male attitudes. Jayanti and TaruBaideo, another actress of that theatre troop, had to go through such problems in their professional life. They are simply an object of desire for men. This can be witnessed in Kolahal and Itihaas also, where both Kiron and Lakhimi, had to face such behavior.

Marriage is that social institution, which makes the woman more subordinate to man. But the meaning and application of the same system is different for both man and woman. 'Marriage 
has always been a very different thing for man and for woman. The two sexes are necessary for each other but this necessity has never brought about a condition of reciprocity between them (Beauvoir 1997:445)'. Same institution permits Mohikanta of Agnisnan to marry another woman in presence of her dutiful and ideal wife. Whether, the same institution restricts her to do the same. The story of Agnisnan is centered with the flexibility and orthodoxy of the marriage system for a man and a woman, which lead a woman to protest against the social norms. In Saikia's oeuvre marriage is defined or placed differently in different situation. If Agnisnan shows marriage as an institution which restricts women's life, Abartan defines marriage as a way to freedom. In Indian society women of one section wants to get married to get rid of their sufferings. Courtesan, film actress and theatre actress come under this category for whom marriage and family life is the path for ultimate freedom. They always want to settle down in their domestic life; which seem impossible in reality. In Abartan also marriage is placed as the ultimate solution of the problem. Jayanti is freed from all bindings through marriage.

Sumanta Banerjee in his writings on Bengali women of nineteenth century makes a distinction between two classes of women who occupied different spaces of the city according to their class position. While, the elite, in new middle-class women, were secluded and stayed indoors in andarmahals (palace interiors), the majority of working women (mostly self-employed as sweepers, owners of stalls selling vegetables or fish, street singers, dancers, and maidservants) performed different activities in public city spaces (Bannerjee: 1997 \& Mazumdar:2007:81). Saikia's women characters are from different sections of the society. Both rural and urban women are projected in his films. Among the urban women also we find two types of women- middle class and working class. In all his films, Saikia's line of distinction in articulating the middle class and working class women is quite similar with that of Banarjee. Sandhyarag is an excellent example 
of such projection. Here, urban middle class women are busy with their household works, while in Kolahal and Itihaas, working class agents, Kiran and Lakhimi had to go outside to earn money. They are forced to perform different works in the urban space. They experience the city in a different way. Saikia constructed the image of these women within the periphery of urbanity. Itihaas represents the precarious life of the female protagonist Lakhimi in the newly formed urban society. This social situation leads her to death. The film had covered the sensitive issue of rape as an urban production. According to Brinda Bose, development of city is analogous with female sexual transgression/ promiscuity with the nation personified as woman (mother, goddess, mistress, prostitute (Bose: 2008: 36). Development of city brings an unsafe life for woman. Transformation of village into city forced Lakhimi to become a part time worker. In this society she is molested by different male members directly or indirectly and the society makes her responsible for all that. At the end of the movie, she is raped, and it compelled her to commit suicide. These kinds of events are common in such societies. In KolahalSaikia had focused on a distinct part of Indian society, which is termed as ‘unintended city’ by Ranjani Mazumdar, where women have to go through massive transformation and transgression. Kiron, the protagonist of Kolahal lived in this 'unintended city', where in the absence of her husband some selfish male members of that area wants to harassed her physically. How the life of a lonely woman becomes measurable in this part of our society is projected in this movie. At the end of the movie Kiron had to accept Badal for a secured life in future. This ending showed that in this 'unintended city', without the support of male member a woman cannot survive. 


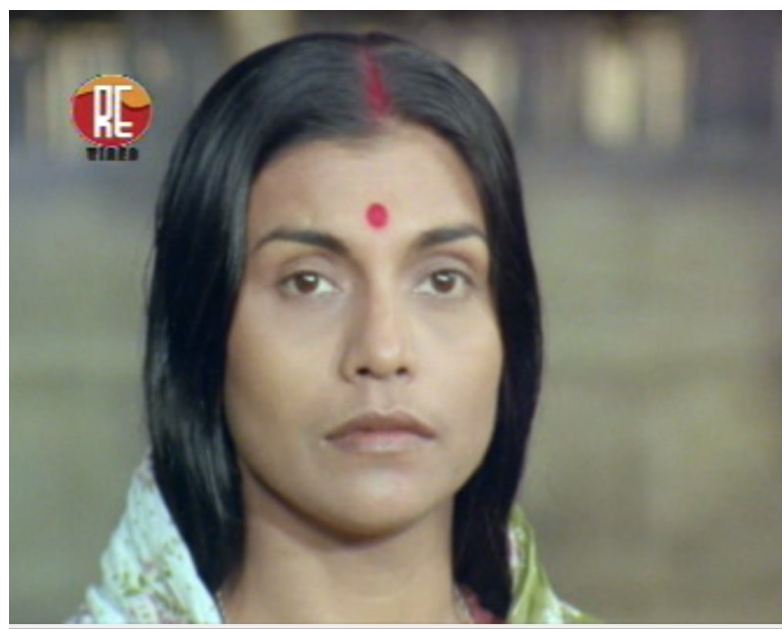

Figure 4: A snapshot from Kolahal

Although, Laura Mulvey's concept of 'male gaze' is not directly applicable to Saikia's movies; yet in some aspects Mulvian concept can help us to understand the narrative composition of the films. The dictionary meaning of the term 'gaze' is to look steadily. But for psychoanalyst and feminist scholar it means more than that. Scholars describe gaze as a 'form of power associated with the eye and with the sense of sight (Cavallaro: 2001:131)'. Gazing is not limited to simply looking at something. 'Gaze probes and masters. It penetrates and objectifies the body (Cavallaro: 2001:131)'. In the process of gazing the one who gazes assumes a position of power as against the one who is looked at. Power of control is associated with this act of gazing and this act is mainly performed by male. Even 'men do not simply look; their gaze carries with it the power of action and of possession which is lacking in the female gaze. Women receive and return a gaze, but cannot act upon it (Kaplan: 1983:31)'.

Saikia's films never objectified woman characters as subject of male gaze. But, in the textual composition of his films -Sandhyarag, Agnisnan, Kolahal and Abartan, the act of controlling can be observed. Here, the gaze is not associated with the act of looking but with the 
controlling of the subject. Within the narrative the male protagonist or his patriarchal ideology controls the woman and in the pro-filmic event the director (who is a male) controls the movement of the story. Saikia's reading of women's issues is highly influenced by the patriarchal ideology. With his famous dictum, "Men act and women appear"- John Berger had described the "conventions of looking in film, which give activity to male characters and passivity to female characters (Fabe: 2004:212)'. These conventions are repeated on the level of film's narrative. "Male characters are traditionally the heroes, the doers, the rescuers, or even the psychotic killers, whereas the women are traditionally the hero's reward, the rescue or the victim" (Fabe:2004:212). This traditional portrayal of woman is repeated again by Saikia also. His films end with the rescuing activity of male protagonist.

Agnisnan is famous for projecting a strong and rebellious woman character. She is bold and determined. She enjoys a prestigious position in the family and outside the family. But her husband's second marriage had shaken her position. She decided to take revenge by establishing an extra marital affair with Madan. Regarding this extra marital relationship C.S. Lakhmi said that, Extra-marital relationship that has become a common theme to portray a "bold" woman. These films seem to generally assume that every woman is justa few orgasms behind liberation. When the customary clandestine orgasms take place, lo and behold, her chains fall off; the world seems a different place and she is carried away on the wings of liberation. When the purity obsession works, it is normally through the body of a woman. A woman, whose physical purity is tarnished, becomes impure. The present "bold" woman portrayals are only an extension of this body obsession. She was bound by her body alone and now she is set free through her body (Lakhmi: 1986:114).

Menaka's involvement in this relationship fulfills her revenge, but at the same time her position is degraded in the society. This form of rebellion by a woman is not available in a preindependent middle-class Assamese society surrounded by traditional codes that prevent them to 
step outside the social bindings. This way of her revenge was highly criticized by film critics and litterateurs. Apurva Sharma and Hiren Gohain has criticized the way taken by Menaka to revolt against the injustice and says that by establishing an illegitimate relationship with a lower class man she has loosen her own position in the society (Gohain: 1993:60). Even at one moment she herself said 'eiyamoikikarilumadan?'(What I have done? Madan). It shows that the way she has chosen is not acceptable for her also. Even at the last conversation with Mohikanta at the rice mill, she said "I don't want to stay in the mud; I also become clean for the society." The concept of purity and impurity is nothing but a patriarchal construction and Menaka accepts this kind of social values and tries to keep her clean. Her body becomes the determinant of her purity and impurity. Her revenge is also kept within her and her husband. Director had chosen the rice mill to disclose Menaka's protest and it signifies that he is not intended to make it a public protest. Absence of female subject is also a greatest flaw of the film. Menaka's relationship with her husband and Madan is in compulsion. Hence, woman projected in the film carrying dual connotation. At denotative level women are projected as independent and strong, but the same women can be an object of desire or suppression for patriarchal system. Because of his male perspective Saikia is unable to understand the reality behind the situation. In this connection we can mention about the style of feminist woman directors like Deepa Mehta or Mira Nair. As female directors they may realize the hidden complexities of woman mind. The women characters of Mehta and Nair's film " travel from being obedient, dutiful virtuous women who honour the family....to women who step outside of tradition to become empowered decision making beings"(Moodley: 2003). They have the capacity to overthrow the patriarchal values. Contrary to that Saikia's female characters either surrender to patriarchy or commit suicide like Lakhami of Itihaas. 
Another important factor in this projection is the transformation of Manaka from a feminine character to a masculine character. As the story develops, Menaka acquires some masculine attributes. Being a representative of the patriarchal society just like her husband Menaka also used the lower-class man Madan for her revenge. As she dominates both Kiron and Madan, there must be a question regarding her identity. Does she represent the feminine identity or she is just a bearer of the patriarchal ideology? From this point of view Menaka cannot be considered as a representative of feminine identity and the film is also not a feminist film. At this juncture we can mention about the observation of Kaplan where she said that,

films in which a woman controls the film's action, it is significant in all these films, when the man steps out of his traditional role as the one who control the whole action, and when he is set up as sex object, the woman then takes on the 'masculine' role as bearer of the gaze and initiator of the action. She nearly always loses her traditionally feminine characteristics in so doing- not those of attractiveness, but rather of kindness, humaneness, motherliness. She is now often cold, driving, ambitious, manipulating, just like the men whose position she has usurped. (1983: 29).

The same process is at work in Saikia's Agnisnan. The film is interesting because it foregrounds a strong and rebellious woman character, but ultimately it also falls under the impact of patriarchal construction. She is able to achieve a powerful position by taking the masculine qualities. In addition to it, Abartan also raised some questions on its realistic representation of women's issues. Like, Agnisnan, in this movie also the protagonist is unable to overthrow the patriarchal system. Besides this, the last part of the movie indicates that the system of exploitation is still continued. It suggests that it is possible for an actress to come out from the theatre party if a man like Parimol wishes to marry her. Thus, Saikia again maintains the traditional way of projection where a suffering woman is always rescued by a man. Even in the middle-class society it is not so easy for a woman with 'dark past' to get marry with an educated man. This is that society where Aideo Handique had to wait a long decade for social acceptance. Therefore, the 
realism behind the character, Parimol can come under question and here the director had crossed the boundary of realism. In this society this kind of step is rarely taken by a highly educated man.

\section{Conclusion:}

To what extent the films of Bhabendra Nath Saikia can be considered as woman's film is another pertinent question raised in this article. The projection of woman in cinema can be uncovered either sociologically or semiotically. The sociological study focused on the role (housewife, beloved, mother, vamp etc.) played by woman in the narrative, whether the entire signifying system of the film where woman is placed, is studied in semiotic analysis. Every text has a denotative and connotative meaning. Connotative meaning is associated with the existing values of that particular society. What the films shows is sometimes vastly different from its suggestive meaning. Say for example, white color signifies peace, purity or widowhood and likewise smoking denotes the boldness of a woman in a film. Feminist scholars draw attention on the connotative meaning of films in woman representation. According to E. Ann Kaplan,

In cinema woman is likewise, as her actual self, a real woman, lifted onto the second level of connotation, myth; she is represented as what she represents for man, not in terms of what she actually signifies. Her discourse (her meaning, as she might produce them) is suppressed in favor of a discourse structured by patriarchy in which her real significance has been replaced by connotations that serve patriarchy's needs" (Kaplan: 1983:18).

The projection of woman's issues on the screen is the outcome of the directorial lens and it, according to Eileen Mcgarry, is coded "first, in the infrastructure of the social formation (human economic practice) and secondly by the superstructure of politics and ideology" (Lakshmi: 1986: 113). Apart from these, gender also plays a significant role in this projection. Directors are not free from his or her gender consciousness and in the composition of cinema proper this consciousness impact a lot. For that reason, a film produced by a male director is 
different from a female director. A female director can understand the hidden complexities of a woman mind more than a male director. This difference is clearly reflected in Saikia's films also.

The debate on the authenticity of representation of women in film is as old as the feminist film criticism. Women stereotype happening in film will leaves a lasting impression on the minds of upcoming generation which create some obstacles in the process of women empowerment. Though Saikia's film has been criticized by many critics, yet it is always remarkable for its attempt to defy the stereotypical projection of woman. In the films he has raised some sensitive issues and at the end tries to give a solution for it. From the films one can easily identify his dual treatment of the narrative as well as form. Saikia's educational background and the socio-political condition of his surrounding enforced him to stay within limitation. As his target audience is the middle class and lower middle-class section of Assam, he is bound to take their sentiments into account in projecting Assamese woman on the screen.

\section{BIBLIOGRAPHY}

Agarwala, J. P. (2003). Asomor Silpa Garhat Asomiya Sarsakar Daitva In Dr. H.Gohained. JyotiPrasad Racanavali. Guwahati: Publication Board.

Bagchi, A. (1996). Women in Indian Cinema.

http://www.cs.jhu.edu/>>bagchi/wpmen.html.Accessed on 19 May 2014.

Beauvoir, S. de (1949). The Second Sex, London: Vintage Books.

Bhattacharya, M. (1979). "Nagarik": RitwikGhatak's First Film. Social Scientist, 8(3), 60-63.

Bhattacharji, S. (1990). Motherhood in Ancient India. Economic and Political Weekly, 25(42/43), WS50-WS57.

Borpujari, M. (2007). New Filmmakers: Rays of Hope, in Barpujari, M. \&Kalita, G. (Eds.) Perspectives on Cinema of Assam. Guwahati: Gauhati Cine Club. pp. 3-12. 
Bose, B. (2008). Modernity, Globality, Sexuality, and the City: A Reading of Indian Cinema. The Global South, 2(1), 35-58.

Butler, J. (1993). Bodies that Matter: On the Discursive Limits of "Sex". New York:Routledge.

Cavallaro, D. (2001). Critical and Cultural Theory: Thematic Variations, London: Athlone Press.

Engels, F. (2004). Origin of the Family, Private Property and the State. Australia: Resistance Books.

Fabe, M. (2004). Closely Watched Films: An Introduction to the Art of narrative Film Techniques. London: University of California Press.

Hayward, S. (2000). Cinema Studies: The Key Concepts. London \& New York: Routledge. 2000

Jones, A. (2003). Introduction: Conceiving the Intersection of Feminism and Visual Culture, in A. Jones ed. The Feminism and Visual Culture Reader. New York: Routledge.

Mazumdar, R. (2007). Bombay Cinema: An Archive of the City, Minneapolis: University of Minnesota Press.

Mazumdar, R. (1991). Dialectic of Public and Private: Representation of Women in Bhoomika and Mirch Masala. Economic and Political Weekly, 26(43), WS81-WS84.

Ganti, T. (2004). Bollywood: Guidebook to Popular Hindi Cinema. London, New York: Routledge.

Gohain, H. (1993). UttaranarSadhanat. Guwahati: Lawyers Book Stall.

Gokulsing, K.M. , and W. Dissanayake. (1988). Indian Popular Cinema: A narrative of Cultural Change. Hyderabad: Orient Longman Pvt. Ltd, 1998. 
Haskell, M. (1987). From Reverence to Rape: The Treatment of Women in the Movies. Chicago: University of Chicago Press.

Huang, J. (2004). Towards a Feminine/Feminist/Female Discourse of Virginia Woolf. Unpublished PhD thesis, Taiwan: National Sun Yat Sen University.

Jain, J., \& Rai, S. (Eds.). (2002). Films and feminism: Essays in Indian cinema. Jaipur: Rawat Publications.

Kaplan. E. A. (1983). Women and Film: Both Sides of the Camera, London: Routledge.

Lakshmi, C. (1986). Feminism and the Cinema of Realism. Economic and Political Weekly, 21(3), 113-115.

Lewis, J. (2003). Cultural Studies: The Basics. New Delhi: Sage Publications.

Macdonald, A. (2009). 'Real' and 'Imagined' Women: A Feminist Reading of Rituparno Ghosh's Films. UCL. 03. pp 1-22.

Madhuri, S. (2009). Women's Bodies as Sites of Signification and Contestation: An Analysis of Deepa Mehta's Critique of Narratives of Home, Nation and Belonging in the Elemental Trilogy, MA dissertation, Bangladesh: University of Dhaka.

McCabe, J. (2004). Feminist Film Studies: Writing the Women into Cinema. London: Wallflower.

Medhi, H. (2014). The Aideo and Her Others: Construction of Gender in Laxminath Bezbarua's Select Writings, in Sarma, M. Madan \& Nath, Debarshi P. (eds) Laxminath Bezbarua: The Architech of Modern Assamese Literature-Issues of Nationalism and Beyond. Guwahati: Perfect Imagers.

Moodley, S. (2003). Postcolonial feminisms speaking through an 'accented' cinema: the construction of Indian women in the films of Mira Nair and Deepa Mehta. Agenda, 17(58), 66-75.

Mulvey, L. (2009). Visual and Other Pleasures (2nd Ed). New York: Palgrave Macmillan. 
Ram, A. (2002). Framing the feminine: Diasporic readings of gender in popular Indian cinema. Women's studies in communication, 25(1), 25-52.

Saikia, P.D. (1992). Economic and Social Status of Rural Women (Non- Tribal) in Assam- A Case Study, In Baruah, S.L (Ed.) Status of Women in Assam (pp-35-50). New Delhi: Orsons Publications.

Senapati, M., Barua, J. (2007). A Path Breaker's Trail, in Barpujari, M. \& Kalita, G.(Eds.) Perspectives on Cinema of Assam (pp. 3-12). Guwahati: Gauhati Cine Club.

Robinson, C. (2011). Working Women on Film: A Realistic Representation? http://dtpr.lib.athabascau.ca/action/download.php?filename=mais/CourtneyRobinsonProject.pdf. Accessed on 14 May 2014.

Singh, I. (2007). Gender Relations and Cultural Ideology In Indian Cinema: A Study of Select Adaptations of Literary Texts. New Delhi:Deep and DeepPublications Pvt. Ltd.

Vasudevan, R. (Ed.). (2000). Making meaning in Indian cinema. New York: Oxford University Press.

Virdi, J. (2003). The cinematic imagiNation: Indian popular films as social history. Newark: Rutgers University Press.

Viswanath, K. (1997). Shame and Control: Sexuality and Power in Feminist Discourse in India. in M.Thapan, (Ed.). Embodiment: Essays on gender and identity. Oxford University Press. 